\title{
THE UNCINATED CRISIS OF GEORGE GERSHWIN
}

\author{
Hélio A.G. Teive1, Francisco M.B. Germiniani', Alexander B. Cardoso3, \\ Luciano de Paola ${ }^{4}$, Lineu César Werneck ${ }^{5}$
}

\begin{abstract}
George Gershwin, renowned composer and pianist, well known for his popular works, died on the $11^{\text {th }}$ July 1937 due to a brain tumor. His neurological symptoms first appeared on that same year, in February, with a simple olfactory partial seizure, characterized by an unpleasant smell of burnt rubber (uncinated seizure). He later had a quick clinical descend, with severe headache that occurred in bouts, dizziness, coordination compromise and olfactory seizures, eventually lapsing into a coma on the $9^{\text {th }}$ July 1937 . It was then that a gliomatosus cyst was diagnosed, which on microscopic examination proved to be a "glioblastoma multiforme". Despite the surgical intervention, Gershwin died soon after the procedure without recovering his consciousness. We make a brief review of Gershwin's neurologic disease, with emphasis on the initial symptoms, namely the uncinated seizures.
\end{abstract}

KEY WORDS: Gershwin, uncinated crisis, glioblastoma.

\begin{abstract}
As crises uncinadas de George Gershwin
RESUMO - O célebre pianista e compositor George Gershwin, renomado pelas suas composições harmônicas e de apelo popular, faleceu em 11 de Julho de 1937 como consequência de um tumor cerebral. Seus sintomas neurológicos tiveram início em fevereiro daquele ano com uma crise epiléptica de tipo uncinado. Posteriormente houve rápida deterioração do quadro com cefaléia intensa, acompanhada por tonturas, até que em 9 de Julho de 1937 Gershwin foi internado em coma, tendo então o diagnóstico de tumor cerebral. Foi realizada a remoção cirúrgica parcial de tumor cístico, cujo exame anátomo-patológico revelou tratar-se de um glioblastoma. Gershwin faleceu logo após a neurocirurgia, sem ter ao menos recobrado a consciência. Fazemos uma breve revisão sobre a enfermidade neurológica de Gershwin, com ênfase aos sintomas iniciais da doença, as crises uncinadas.
\end{abstract}

PALAVRAS-CHAVE: Gershwin, crises uncinadas, glioblastoma.

George Gershwin, renowned composer and pianist, well known for his popular works, died on the $11^{\text {th }}$ July 1937 due to a brain tumor. His neurological symptoms first appeared on that same year, in February, with a simple olfactory partial seizure, characterized by an unpleasant smell of burnt rubber (uncinated seizure) ${ }^{1,2}$. The aim of our study is to review the medical history of Gershwin's disease, particularly his uncinated seizures.

\section{Biography}

Born in New York on the $26^{\text {th }}$ September, 1898, to a family of Jewish- Russian immigrants, George Gershwin spent most of his childhood in Manhattan's Low East Side, where his father worked. Originally, his family name was Gershwin, an American adaptation taken by his father, Morris Gershovitz soon after he had immigrated to the USA ${ }^{1}$. Gershwin had other three brothers; the eldest, Ira, worked with George on many songs as a great lyrics writer and of all siblings was the one who most closely followed George's musical career. Gershwin first became interested in music when he was about ten years old after befriending Maxie Rosenzweig, who was already a violin virtuoso at eight years of age, and who also had a brilliant career as a professional solist. Under Maxie's influence, Gershwin took possession of the piano initially intended for Ira, dazzling everyone whenever he played popular songs that he had learnt just by listening. Professor Ambitzer also pressed Gershwin further by refining his piano technique and making him attend concerts. He finally made his public debut on the $21^{\text {st }}$ March, 1914 playing a tango he had composed himself. He quit school at fifteen in order to work as a pianist at Remock's, for just fifteen dollars a week ${ }^{1}$.

Serviço de Neurologia, Departamento de Clínica Médica, Hospital de Clínicas, Universidade Federal do Paraná (UFPR), Curitiba PR, Brasil: ${ }^{1}$ Professor Assistente de Neurologia; ${ }^{2}$ Médico Residente de Neurologia (R3); ${ }^{3}$ Médico; ${ }^{4}$ Neurologista; ${ }^{5}$ Professor Titular de Neurologia.

Received 21 September 2001, received in final form 16 November 2001. Accepted 3 December 2001.

Dr. Hélio Teive - Rua General Carneiro 1103/102 - 80069-900 Curitiba PR - Brasil. Fax: 41244 5060. E-mail: hagteive@mps.com.br 
A prolific composer, Gershwin composed many songs that became quite famous, such as Rhapsody in Blue, An American in Paris , Concert in F, Porgy and Bess and the Cuban Overture ${ }^{1}$. He first started composing Rhapsody in Blue on the seventh of January 1924 and he finished the piece on the 4th February 1924 , less than one week before the opening concert. Thankfully it turned out to be a huge success among both the ley people and the critics ${ }^{1}$. In 1927 Gershwin started working on his third orchestral play, An American in Paris, two years after Concert in $F$. The $13^{\text {th }}$ December marked the first presentation of An American in Paris, played by the Philharmonic Society Orchestra at the Carniege Hall, with Walter Damrosch as the conductor. It was so successful that it was "a tone poem for orchestra"1. A few years later, in 1932, a quick vacation spent in Cuba served as inspiration for his Cuban Overture, an orchestrated rumba'.

In 1934, Gershwin finally began his work on Porgy and Bess, with DuBose Heyward. In order to finance such a huge project, Gershwin had a radio program called Music by Gershwin. At that time he also composed I got The Rhythm, which was enthusiastically played wherever he went in his American tour. Porgy and Bess debuted at the Alvin Theater in 1935 and in 1936 Gershwin unveiled another magnificent piece, Shall We Dance in Hollywood. But it was in 1937, while conducting the Los Angeles Symphony Orchestra's rendition of Concert in F, that he presented with his first neurological symptoms ${ }^{1,2}$.

George Gershwin died when he was only 38 . He was certainly one of the musical geniuses of the twentieth century, making the hitherto unparalleled marriage of popular and classical music. In Charles Schwartz's words "composing popular songs requires special talents. Gershwin had an abundance of those talents. To him, composing songs was like a child's play. He loved to create them: they came to him so easy and naturally as soon as he sat by his piano. Many of his works reflected that spontaneity, as well as his own evolution as a pianist"1,2.

\section{The beggining of the lethal disease}

An extrovert, it was not until half of 1936 that Gershwin started experiencing increasingly longer spells of melancholy, showing no physical changes whenever he visited his physician. It was not until the following year, during a presentation of his Concert in $\mathrm{F}$ by the Los Angeles Symphony Orchestra, conducted by Alexander Smallens, that Gershwin had the first signs of his fatal disease ${ }^{1,2}$. While playing he experienced a "mental lapse" for a few seconds making a blunt mistake. Even though nobody seemed to notice it, that brief mistake was strikingly significant to Gershwin, who had never committed such a mistake. He mentioned that fact to his private physician, Dr. Zilboorg, recalling a smell of burnt rubber at the same time that he "blacked out". Dr. Zilboorg, a Psychiatrist, told Gershwin that that symptom would probably be organic in origin and Gershwin underwent a thorough medical examination in February. The examination disclosed no significant changes and he was diagnosed as suffering from some sort of psychosomatic disorder and a "defense mechanism". In spite of all that, he would later experience again the same symptoms at a barber's shop, losing consciousness for roughly half a minute ${ }^{2}$.

At the beginning of 1937, Gershwin started complaining of headaches and dizziness spells, which he attributed to overworking. By Zilboorg's instructions, Gershwin was examined by Dr. Ernest Simmel, who diagnosed his symptoms as being psychosomatic. He later consulted with Dr. Gabriel Segall, as his headache and dizziness spells became more severe. He stressed that his dizziness spell were characterized by vertigo and an unpleasant smell lasting around 30 seconds. These spells occurred mostly in the morning, soon after waking up and were also presented whenever he got nervous, as when he was playing during a concert or when he played tennis. He never lost consciousness, but Dr. Segall recommended a careful study of the spinal fluid, which Gershwin denied, believing that it would be just a matter of time before his symptoms faded away $y^{2-4}$.

In 1937 Gershwin was first admitted to the "Cedars of Lebanon" Hospital, in Los Angeles, in order to investigate a progressively worsening fronto-temporal headache, which was more intense in the morning and with other symptoms such as nausea, dizziness and recurring olphactory hallucinations. His relatives also complained of paroxysmal behaviour changes, like the one in which, soon after receiving a chocolate as a gift, he powdered it and started rubbing it against his own body as an ointment. At yet another time, Gershwin opened the door of his moving car, in an attempt to throw his driver out of it. At that time he also complained of some motor limitations, letting objects fall from his right hand and motor incoordination especially while climbing a flight of stairs. His neurologic examination, performed by Dr. Eugene Ziskind was normal and so were several blood tests, skull X-rays,, EKG and Wasseman's test. The diagnosis at the time of his hospital discharge was of "hysteria"2-4. 
Gershwin's uncinated seizures

The first symptom of Gershwin's disease were spells of dizziness accompanied by the peculiar smell of "burnt rubber" with neither compromise of consciousness nor involuntary tonic and/ or clonic jerks ${ }^{1,-4}$.

Based on those features, his seizures could be interpreted as simple partial seizures with olfactory auras $^{5}$. The first reports of such seizures date back some centuries ago, but it was in 1899 that Hughlings Jackson dubbed the seizures which presented with "a harsh smell or taste" as "uncinated seizures" $^{\prime \prime, 6}$ In reality, these seizures are mostly reported as "unpleasant" sensations, such as the reports of Gershwin himself. Olfactory auras are rather rare, especially if one compares them with other types of simple partial seizures. They account for $0.9 \%$ of all auras, but according to different series their real incidence ranges from 1.6 to $16 \%$. Not only their true incidence is a matter of discussion, but also their true etiology and the anatomical structures affected in such cases. This is most probably due to the small amount of studies that focus solely on olfactory auras, as those are reported mostly as a single group in series evaluating a broader spectrum of auras ${ }^{6}$.

It is a rather common belief that those seizures are almost always directly related to a brain tumor, as in Gershwin's case, but this concept has recently been questioned, particularly after the report of a large series of patients with temporal lobe epilepsy due to hyppocampal sclerosis?.

The exact anatomical origin of olfactory auras is also a matter of discussion, and both the mesio-temporal and orbito-frontal regions have been considered as possible epileptogenic sources of such seizures. The particular sensation felt by the patients who suffer from uncinated seizures has been elicited by independent electrical stimulation of the amigdala and the olfactory bulb, making the possibility of a sole anatomical origin rather unlikely ${ }^{6}$.

Acharya et al. performed an elaborate study of 13 patients, among a larger group of 1423 patients with partial seizures, who were evaluated for 5 years. Both invasive and non-invasive video-electroencephalography, as well as structural end functional neuroimaging exams, were used and the sum of all the data made for an exquisitely well designed study. Some specially interesting findings were a) that only 7 patients had a really unpleasant olfactory sensation (some patients reported the smell of barbecue, flowers, peanut butter, alcohol or a "funny smell"); b) 12 of the thirteen patients had complex partial seizures, or even secondarily generalized seizures, following the onset of the olfactory seizures - this pro- ved that isolated olfactory seizures are quite rare (even Gershwin had at least once an impairment of consciousness), c) ictal mesial activity was found in all patients; d) ten patients had tumor as their epileptogenic source; e) the hippocampus was never the sole source of ictal discharges, and the amigdala is probably the true source of the symptoms of olfactory seizures; and finally f) hyppocampal sclerosis is seldom found in association with this type of seizure $^{6}$.

Seizures due to hippocampal sclerosis can be associated with olfactory sensations, but these sensations are different from the classically reported olfactory seizures. In 1997 Baumgartner et al. ${ }^{8}$ reported a patient who had right hippocampal sclerosis, whose seizures were initially interpreted as an unpleasant smell of onions. Later it was proved that this patient suffered from right olfactory agnosia. Even though it is but one single report, the authors proposed that a better semiological study of olfactory sensations in epileptic patients should be performed ${ }^{8}$.

Gershwin always complained of a rather odd epigastric sensation, which he could not clearly describe, which was diagnosed as chronic neurosis, spastic colitis and "composer's stomach"1,2. An ascending epigastric sensation is classically described in patients suffering from temporal lobe epilepsy due to hippocampal sclerosis ${ }^{9}$, but is by no means an exclusive feature of that pathology. It is possible that Gershwin actually had two distinct types of partial seizures.

\section{The final event}

Gershwin played the piano for the last time in the morning of the $9^{\text {th }}$ July 1937 . At that time he could still sit in front of his piano, but by the evening's end he was already in a coma. He was then taken to the Cedars of Leban Hospital, where he was first treated with a venous infusion of sucrose $50 \%{ }^{1-4}$.

He was examined by Dr. Carl Rand who reported that Gershwin could not be awakened even by compression $f$ the supra-orbital nerve. Nevertheless, he could at times move a leg or an arm, but could not make any voluntary movements. His pupils were small, anysochoric, but still reacted to light. Fundoscopic examination disclosed pappiledema, signs of recent retinal hemorrhages and ingurgitated vessels. His right arm and leg were almost as still as his left limbs, but after a painful stimulus the right limbs reacted in an unspecific fashion. His blood pressure was $105 / 60 \mathrm{mmHg}$. Abdominal reflexes could be elicited on the left side, but not on the right one. Deep tendon reflexes were reduced bilaterally. Stiff neck or Kernig's sign could not be found ${ }^{2-4}$. 
A spinal tap disclosed an initial pressure of 400 $\mathrm{mmH} 2 \mathrm{O}$ which quickly fell to $220 \mathrm{~mm} \mathrm{H} 2 \mathrm{O}$ after 6 $\mathrm{ml}$ of cerebrospinal fluid (CSF) were obtained. CSF was clear, with just one leukocyte and $30 \mathrm{mg}$ of protein ${ }^{2}$.

His condition worsened slowly and by 09:30 am in the $10^{\text {th }}$ July his family was told that his prognosis was bleak. He had bilaterally increased deep tendon reflexes, with clonus in both hands and bilateral Babinski's sign. Abdominal and cremasteric reflexes were absent. Chaddock's sign could be found at times, as well as Hoffman's sign on the left side and he still had bilateral movements to pain. He was diagnosed as suffering from an expansive tumoral lesion and prompt surgical treatment should be done as quickly as possible ${ }^{2-4}$.

Renowned neurosurgeon, Dr. Harvey Cushing was called but he refused to operate on Gershwin as he had been retired for some time and feared that his reflexes should not be as accurate as they once had been. He recommended Dr. Walter Dandy, of the John Hopkins Hospital, but several attempts to contact him were to no avail. At the invitation of Harry W. Nice, Maryland's Governor, he had left on a cruise. Two friends of Gershwin's acted independently from each other, making dramatic attempts to help their common friend. George Pallay, from California, went to the White House to ask for help while Emil Mosbacher, a New York stockbroker made a plea of help to the Coast Guard. Dr. Dandy was found on Chesapeake Bay, in the official yacht Du Pont and the Coast Guard ushered him to Cambridge, from where he flew to Newark. A private plane, arranged by Mosbacher, awaited him, ready to take him to California. However, when he talked to Gershwin's doctors on the phone, Dr. Dandy was told that he would probably arrive too late to perform the surgery and the trip was cancelled ${ }^{2-4}$

Dr. Howard C. Naffziger, Professor of the Faculty of Medicine of the California University was found at the Lake Tahoe in Nevada, where he was vacationing. He arrived at the Cedars at 09:30 in the evening of the $10^{\text {th }}$ July and at that same evening, both Drs. Rand and Naffzinger performed the trepanation, in order to perform a ventriculography to locate the tumor. The fourth ventricle was compressed and dislodged to the left, the third ventricle was widened and also dislodged laterally. These findings were suggestive of a compressive tumor in the right temporal lobe ${ }^{2-4}$.

Dr. Rand performed the craniotomy, exposing the dura, underneath which a gliomatous cyst (glioblastoma multiforme, later confirmed by pathological study) was found. Drainage of the cyst disclosed an yellowish fluid content. The cyst was opened and at the bottom of it a wall nodule was found. The nodule was then removed and the cyst's wall was cauterized. The dura was left open and the surgical wound sutured with black silk. The whole procedure took about five hours. Soon after, Gershwin's temperature rose to $105.6 \mathrm{~F}$, his pulse was 180 beats per minute and his respirations were 45 per minute. Five hours after the surgery, at 10:35am, July 11, 1937, Gershwin died ${ }^{2-4}$.

News of Gershwin's death spread quickly throughout the world and there were several public displays of hurt and tributes to his memory. Dr. Dandy, in a letter to Dr. Segall, commented on the difficulties found at the surgery and the late diagnosis: "I can't fathom what could possibly be done for Mr. Gershwin. It was one of those fulminating tumors. There are only a handful of removable tumors, and I believe that, even though a great part of the tumor was removed and he could have had a brief recovery, he would soon relapse, as the disease was rather fulminating from the very beginning. I believe that it was the best outcome for him, since for a brilliant man a recurring tumor would be but a terrible, slow death"2.

\section{REFERENCES}

1. Schwartz C. Gershwin: uma biografia. São Paulo: José Olympio Editora, 1993.

2. Carp L. George Gershwin: illustrious American composer. His fatal glioblastoma. Am J Sur Pathol 1979;3:473-477.

3. Ljunggren B. The case of George Gershwin. Neurosurgery 1982;10:733736.

4. Silverstein A. Neurologic history of George Gershwin. Mt Sinai J Med 1995;62:239-242.

5. Wyllie E. The treatment of epilepsy: principles and practice. Baltimore: Williams \& Wilkins,1993:380-381.

6. Acharya V, Acharya J, Luders H. Olfactory epileptic auras. Neurology 1998;51:56-60.

7. Fried I, Spencer DD, Spencer SS. The anatomy of epileptic auras: local pathology and surgical outcome. J Neurosurg 1995;83:60-66

8. Baumgartner $\mathrm{Jl}$, Serles W, Olbrich A et al. Olfactory prodromal symptoms and unilateral olfactory dysfunction are associated in patients with right mesial temporal lobe epilepsy. Epilepsia 1997;38:1042-1044.

9. Kotagal P. Seizure symptomatology of temporal lobe epilepsy. In Luders H. (ed). Epilepsy surgery. New York: Raven Press, 1992:143-155. 